\title{
PENGARUH VARIASI KONSENTRASI ASAM SITRAT DAN ASAM TARTRAT TERHADAP SIFAT FISIK GRANUL EFFERVESCENT DARI EKSTRAK DAUN NANGKA (Artocarpus heterophyllus L.)
}

\author{
Nor Zuraidah", ${ }^{1,}$, Welinda Dyah Ayu ${ }^{1}$, Mirhansyah Ardana ${ }^{1,2}$ \\ ${ }^{1}$ Laboratorium Penelitian dan Pengembangan Kefarmasian "Farmaka Tropis", \\ Fakultas Farmasi, Universitas Mulawarman, Samarinda, Indonesia \\ ${ }^{2}$ Kelompok Bidang Ilmu Farmasetika dan Teknologi Farmasi, Fakultas Farmasi, \\ Universitas Mulawarman, Samarinda, Indonesia \\ *Email: norzuraidah97@ gmail.com
}

\begin{abstract}
Jackfruit (Artocarpus heterophllus L.) leaves contain chemical compounds have antioxidant effects. Based on the pharmacological effects, one of the pharmaceutical preparations can be formulated is effervescent granules. The purpose of this research to know about the variations concentration of citric acid and tartric acid on the physical properties of granules include organoleptic, flow rate, angle of repose, density, compressibility, $\mathrm{pH}$ of solution, dispersion time and moisture content test. The extract of jackfruit leaves was done by maceration, using $96 \%$ ethanol. Effervescent granules made into 3 formulas with variations in concentration of citric acid and tartrate acid F1 (1:2), F2 (1:1), and F3 (2:1) using a wet granulation. Data for the physical properties of granules obtained were analyzed using a theoretical approach. The results showed that the ratio of tartrate and citric acid affect on the physical properties in effervescent granules with F1 which the most qualified compared F2 and F3 especially at flow rate, angle of repose, $\mathrm{pH}$ of solution, and dispersion time.
\end{abstract}

Keywords: Artocarpus heterophyllus L., citric and tartaric acid, effervescent granule

\begin{abstract}
ABSTRAK
Daun nangka (Artocarpus heterophllus L.) mengandung senyawa kimia yang memiliki efek antioksidan. Berdasarkan efek farmakologi tersebut, sediaan yang dapat diformulasikan adalah granul. Penelitian ini bertujuan mengetahui pengaruh variasi konsentrasi asam sitrat dan asam tartrat terhadap sifat fisik granul effervescent meliputi organoleptik, laju alir, sudut diam, densitas, kompresibilitas, $\mathrm{pH}$ larutan, waktu dispersi dan kelembaban. Penyarian daun nangka dilakukan dengan maserasi, menggunakan etanol 96\%. Granul effervescent dibuat menjadi 3 formula dengan variasi konsentrasi asam sitrat dan asam tartrat F1(1:2), F2(1:1), dan F3(2:1) menggunakan metode granulasi basah. Data uji sifat fisik granul dianlisis dengan pendekatan teoritis. Hasil penelitian menunjukkan bahwa variasi konsentrasi asam sitrat dan asam tartrat berpengaruh terhadap sifat fisik granul effervescent dengan menghasilkan F1 yang paling memenuhi persyaratan
\end{abstract}


dibandingkan F2 dan F3 yaitu pada nilai laju alir, sudut diam, pH larutan dan waktu dispersi.

Kata kunci: Artocarpus heterophyllus L., asam sitrat dan tartrat, granul effervescent

DOI: https://doi.org/10.25026/mpc.v8i1.302

\section{PENDAHULUAN}

Obat tradisional telah lama dikenal dan digunakan oleh masyarakat Indonesia[9]. Salah satu spesies tumbuhan yang banyak di Indonesia adalah Artocarpus heterophyllus L. yang dikenal dengan tanaman nangka. Penduduk di berbagai daerah di Indonesia tidak hanya menggunakannya sebagai bahan pangan, tetapi juga sebagai obat tradisional seperti luka, bisul, dan penyakit kulit [11]. Berdasarkan penelitian sebelumnya daun nangka mengandung senyawa flavonoid, alkaloid, saponin, steroid dan tanin [8]. Kemudian didapatkan hasil isolasi etanol daun nangka senyawa flavonoid sebesar $7,55 \mathrm{mg} / \mathrm{g}$ [1]. Penggunaan daun nangka di masyarakat untuk pengobatan masih sangat sederhana yaitu dengan cara direbus lalu disaring dan air rebusannya diminum [9].

Selain penggunaanya secara empiris daun nangka juga telah diteliti melalui penelitian farmakologi untuk mengetahui efektivitasnya dalam mengobati diabetes. Berdasarkan penelitian sebelumnya menyatakan bahwa tanaman ini memiliki efek antioksidan pada tikus yang diinduksi diabetes dengan dosis $200 \mathrm{mg} / \mathrm{kg}$ BB [10].Untuk penggunaan daun nangka sebagai obat yang lebih praktis daun nangka dapat dibuat menjadi sediaan dalam bentuk granul effervescent. Keuntungan dari bentuk sediaan ini adalah dalam hal penyiapan larutan dalam waktu seketika mengandung dosis obat yang tepat. Sediaan effervescent juga menghasilkan rasa yang enak karena adanya karbonat yang membantu memperbaiki rasa beberapa obat tertentu [9].

Dalam formulasi granul effervescent selain zat aktif ada juga beberapa bahan tambahan yang digunakan, salah satu bahan tambahan yang dimaksud yaitu sumber asam. Dalam penelitian ini menggunakan dua sumber asam yaitu asam sitrat dan asam tartrat. Karena penggunaan bahan asam tunggal akan menimbulkan kesukaran. Penggunaan asam sitrat sebagai asam tunggal membuat campuran lengket dan sulit menjadi granul, sedangkan penggunaan asam tartrat tunggal membuat granul mudah menggumpal [2]. Asam sitrat dan asam tartrat memiliki sifat masing-masing yang apabila dicampur akan berpengaruh terhadap sifat fisik dari garnul yang dihasilkan. Granul effervecent ekstrak daun nangka dibuat dengan variasi konsentrasi asam sitrat dan asam tartrat F1(1:2). F2(1:1), dan F3 (2:1).

Penelitian ini bertujuan untuk memperoleh berapa jumlah rendemen dari ekstrak daun nangka, mengetahui sifat fisika ekstrak daun nangka, dan mengetahui pengaruh variasi konsentrasi asam sitrat dan asam asam tartrat terhadap sifat fisik granul effervescent ekstrak daun nangka meliputi organoleptik, laju alir, sudut diam, densitas, kompresibilitas, pengujian $\mathrm{pH}$ larutan, pengujian waktu dispersi, dan kelembaban. 


\section{METODE PENELITIAN}

\begin{abstract}
Alat
Peralatan yang digunakan dalam penelitian ini adalah Ayakan 20 mesh, batang pengaduk, cawan porselin, corong kaca, corong buchner, desikator, flow meter, gelas kimia, hot plate, labu ukur, loyang, mangkok kaca, moisture analyzer, mortir, oven, penggaris, penjepit krus, $\mathrm{pH}$ meter, pipet tetes, pipet ukur, propipet, rotary evaporator, sendok tanduk, spatel, stopwatch, timbangan analitik, toples kaca, dan mechanical tapping device.
\end{abstract}

\section{Bahan}

Bahan yang digunakan pada penelitian ini adalah aquades, asam sitrat, asam tartrat, daun nangka (Artocarpus heterophyllus L.), etanol 96\%, kertas perkamen, kertas saring, kloroform, laktosa, natrium bikarbonat, polivinil pirolidon (PVP K30).

\section{Pengumpulam bahan tumbuhan}

Dikumpulkan sampel daun nangka yang diambil dari daerah Perjuangan, Samarinda, Kalimantan Timur. Dibersihkan dari kotoran yang menempel pada bagian-bagian daun. Ditimbang berat sampel segar $8 \mathrm{~kg}$. Dikeringkan dengan cara dioven suhu $50^{\circ} \mathrm{C}$. Dirajang sampel tersebut menjadi potongan yang kecil. Diperoleh simplisia kering untuk sampel yang siap untuk dilakukan proses ekstraksi. Ditimbang bobot simplisia kering (didapatkan 800 gram simplisia).

\section{Ekstraksi}

Ditimbang simplisia sebanyak 800 gram. Diekstraksi dan dimasukkan kedalam toples transparan yang tertutup dengan baik dan rapat. Dimaserasi dengan etanol $96 \%$ sebanyak 3,5 liter. Dilakukan pengadukan sesekali. Didiamkan selama 3 hari hingga warna pelarut menjadi pekat. Ditampung maserat (hasil maserasi pertama). Diulangi perlakuan tersebut hingga diperoleh pelarut berwarna bening. Dipekatkan maserat dengan menggunakan rotary evaporator hingga diperoleh ekstrak kental. Dikeringkan dengan diangin-angikan pada suhu ruang hingga diperoleh ekstrak pekat. Dihitung hasil pemekatan maserasi. Disimpan ekstrak dalam desikator.

\section{Karakteristik sifat fisika dan kimia ekstrak}

\section{Organoleptis}

Penetapan organoleptis menggunakan panca indera dalam mendeskripsikan wujud, warna, dan aroma.

\section{Kadar senyawa larut air}

Sejumlah 1 gram ekstrak disari selama 24 jam dengan $20 \mathrm{~mL}$ aquadeskloroform (Larutan Pereaksi), menggunakan labu bersumbat sambil berkali-kali dikocok selama 6 jam pertama dan kemudian dibiarkan selama 18 jam, disaring. Diuapkan $20 \mathrm{~mL}$ filtrat hingga kering dalam cawan penguap, residu dipanaskan pada suhu $105^{\circ} \mathrm{C}$ hingga bobot tetap. Dihitung kadar dalam persen senyawa yang larut dalam air terhadap berat ekstrak awal [5].

\section{Kadar senyawa larut etanol}

Sejumlah 1 gram ekstrak dimaserasi selama 24 jam dengan $100 \mathrm{~mL}$ etanol $96 \%$ menggunakan labu bersumbat sambil berkali-kali dikocok selama 6 jam pertama dan kemudian dibiarkan selama 18 jam. Disaring cepat dengan menghindari penguapan etanol, kemudian diuapkan $20 \mathrm{~mL}$ filtrat hingga kering dalam cawan penguap yang telah ditara, residu dipanaskan pada suhu $105^{\circ} \mathrm{C}$ hingga bobot tetap. Dihitung kadar dalam persen senyawa yang larut dalam etanol terhadap berat ekstrak awal [5].

\section{Penetapan kadar air}

Penetapan kadar air menggunakan alat moisture analyzer. Sebanyak 0,5 
gram sampel ekstrak dimasukkan ke dalam alat moisture analyzer, ditunggu sampai alat menunjukkan hasil kadar air dalam satuan persen (\%). Suhu diatur $105^{\circ} \mathrm{C}$ dan ditunggu selama 30 menit [4]. Berdasarkan MMI dan KEPMENKES RI syarat kadar Air harus $<10 \%$.

\section{Formula granul effervescent}

Tabel 1. Formula granul effervescent ekstrak daun nangka

\begin{tabular}{lccc}
\hline \multirow{2}{*}{ Komposisi } & \multicolumn{3}{c}{ Formula (\%) } \\
\cline { 2 - 4 } & 1 & 2 & 3 \\
\hline Ekstrak Daun Nangka & 13,33 & 13,33 & 13,33 \\
PVP K30 & 2 & 2 & 2 \\
Asam Sitrat & 13,3 & 20 & 26,7 \\
Asam Tartat & 26,7 & 20 & 13,3 \\
Natrium Bikarbonat & 40 & 40 & 40 \\
Laktosa & 4,5 & 4,5 & 4,5 \\
\hline
\end{tabular}

\section{Pembuatan granul dengan metode granulasi basah}

Granul effervescent dibuat secara terpisah antara granul asam dan granul basa untuk menghindari reaksi effervescent dini. Ekstrak ditimbang dan dilarutkan dengan etanol $96 \%$ dalam gelas kimia, kemudian dibuat granul asam dengan mencampur asam sitrat, asam tartrat, dan laktosa. Sedangkan granul basa terdiri dari natrium bikarbonat. Kemudian PVP K30 dibasahi dengan larutan etanol ekstrak sampai terbentuk mucilago. Lalu dicampurkan granul asam dan granul basa ke dalam mucilago dan dilakukan pengeringan dengan oven pada suhu 40$60^{\circ} \mathrm{C}$ sampai terbentuk massa yang akan digranulasi. Massa yang akan digranulasi kemudian diayak dengan ayakan 20 mesh. Granul kemudian dikeringkan dengan oven pada suhu 40$60^{\circ} \mathrm{C}$. Setelah kering granul diayak dengan ayakan 20 mesh supaya mendapat granul dengan ukuran yang homogen.

Pembuatan granul effervescent dilakukan ditempat dengan suhu ruangan dan kelembaban udara terjaga.
Setelah terbentuk granul diuji sifat fisiknya.

\section{Karakteristik sifat fisik granul effervescent}

\section{Laju alir}

Laju alir dilakukan dengan menggunakan alat flow meter. 10 gram granul dimasukkan ke dalam alat dan dicatat waktu yang diperlukan granul untuk jatuh.

\section{Sudut diam}

Sudut diam dilaukan dengan dimasukkan granul kedalam corong pada flow meter yang dipasang dengan jarak $10 \mathrm{~cm}$ dari ujung bawah corong hingga permukaan datar, lalu dihitung waktu yang diperlukan granul untuk mengalir dan dihitung diamter serta tinggi kerucut yang terbentuk.

\section{Densitas}

Data densitas diperoleh dengan menimbang berat gelas ukur $25 \mathrm{~mL}$ kosong lalu dimasukkan granul kedalam gelas ukur hingga mencapai volume 25 $\mathrm{mL}$ lalu dicatat dan dihitung nilai bulk densitynya dan dilakukan pengetapan 
pada gelas ukur sebanyak 500 kali, kemudian diukur volume dan ditimbang massa granul lalu dihitung nilai tapped densitiynya.

\section{Kompresibilitas}

Penentuan nilai indeks kompresibiltas dilakukan dengan berdasarkan data yang diperoleh dari perbandingan dan selisih antara bulk density dan tapped density.

\section{Kelembaban}

Nilai kelembaban diperoleh dengan menggunakan alat moisture analyzer. Sebanyak 0,5 gram granul dimasukkan ke dalam alat moisture analyzer, ditunggu sampai alat menunjukkan hasil dalam satuan persen. Suhu diatur $120^{\circ} \mathrm{C}$ dan ditunggu nilai kelembaban muncul pada alat.

\section{pH larutan}

Nilai pH diperoleh dengan menggunakan alat $\mathrm{pH}$ meter yang dilakukan dengan cara melarutkan 5 gram granul effervescent ke dalam $100 \mathrm{~mL}$ aquadest. Setelah larut sempurna pengukuran $\mathrm{pH}$ dilakukan menggunakan $\mathrm{pH}$ meter,

\section{Waktu larut}

Data waktu larut atau dispersi diperoleh dengan memasukkan $100 \mathrm{~mL}$ aquadest dengan suhu $15-25^{\circ} \mathrm{C}$ ke dalam gelas kimia. Setelah itu dimasukkan 15 gram granul ke dalam air tersebut dan dicatat waktu yang diperlukan granul untuk menyelesaikan reaksinya didalam aquadest.

\section{HASIL DAN PEMBAHASAN}

\section{Karakteristik sifat fisika dan kimia ekstrak}

Pada penelitian ini menggunakan daun nangka yang telah dikeringkan dan diserbuk haluskan. Daun nangka ditimbang sebanyak 800 gram lalu dimaserasi dengan pelarut etanol $96 \%$ selama 3 hari. Maserat kemudian didestilasi vakum, didapatkan 91,88 gram ekstrak kental. Daun nangka juga telah dideterminasi yang dilakukan di Laboratorium Dendrologi dan Ekologi Hutan Fakultas Kehutanan Universitas Mulawarman dan hasil identifikasi/ determinasi menyatakan bahwa spesies tanaman yang digunakan adalah benar Artocarpus heterophyllus L.

Karakteristik sifat fisika dan kimia penting dilakukan untuk menjamin mutu dari simplisia dan ekstrak yang akan digunakan. Berikut hasil penetapan sifat fisika dan kimia dapat dilihat pada tabel 2.

Tabel 2. Karakteristik sifat fisika ekstrak daun nangka

\begin{tabular}{ll}
\hline \multicolumn{1}{c}{ Parameter } & \multicolumn{1}{c}{ Hasil } \\
\hline Organoleptik ekstrak & $\begin{array}{l}\text { Warna:hijau kehitaman } \\
\text { Aroma: kuat } \\
\text { Wujud: kental }\end{array}$ \\
Kadar senyawa larut dalam: & \\
- Air & $29,3100 \%(>5,5 \%)$ \\
- Etanol & $37,6333 \%(>2,5 \%)$ \\
Kadar air & $6,6033 \%(<10 \%)$ \\
\hline
\end{tabular}


Tabel 3. Hasil evaluasi sifat fisik granul effervescent

\begin{tabular}{lcccc}
\hline \multirow{2}{*}{ Parameter } & & \multicolumn{3}{c}{ Granul Effervescent } \\
& & F1 & F2 & F3 \\
\hline & Aroma & $\begin{array}{c}\text { Khas Daun } \\
\text { nangka }\end{array}$ & $\begin{array}{c}\text { Khas Daun } \\
\text { nangka }\end{array}$ & $\begin{array}{c}\text { Khas } \\
\text { Daun } \\
\text { nangka }\end{array}$ \\
& & Padatan & Padatan & Padatan \\
Organoleptik & Bentuk & kecil & kecil & kecil \\
& Warna & Hijau tua & Hijau tua & Hijau tua \\
Laju Alir (g/s) & & 13,0952 & 11,5740 & 11,1111 \\
Sudut Diam ( $\left.{ }^{\circ}\right)$ & & 17,5534 & 20,3921 & 21,4645 \\
Indeks Kompresibilitas $(\%)$ & & 8,6678 & 7,3365 & 12,6658 \\
Kelembaban (\%) & 7,7166 & 5,4500 & 5,7266 \\
pH larutan & & 5,45 & 5,24 & 5,18 \\
Waktu larut (detik) & & 63 & 70 & 98 \\
\hline Kenangan & & &
\end{tabular}

Keterangan:

$\mathrm{F} 1=$ Granul effervescent perbandingan asam sitrat dan asam tartrat 1:2

$\mathrm{F} 2=$ Granul effervescent perbandingan asam sitrat dan asam tartrat 1:1

$\mathrm{F} 3=$ Granul effervescent perbandingan asam sitrat dan asam tartrat 2:1

Penetapan organoleptik ekstrak dan simplisia daun nangka menunjukkan bahwa simplisia memiliki karakteristik berwarna hijau kecoklatan dan beraroma khas lemah daun nangka, dan organoleptik ekstrak daun nangka memiliki karakteristik berwarna hijau kehitaman, beraroma kuat daun nangka, dan berwujud kental.

Penetapan senyawa larut air dan etanol dilakukan untuk mengetahui jumlah senyawa yang dapat terlarut/tersari dari simplisia dengan menggunakan pelarut air dan etanol [6]. Hasil pengujian menunjukkan kadar senyawa larut air ekstrak daun nangka sebesar 29,31\% dan kadar senyawa larut etanol ekstrak daun nangka sebesar 36,76\%. Keduanya memenuhi persyaratan yang ditetapkan MMI. Hal ini menunjukkan bahwa senyawa pada ekstrak daun nangka lebih banyak tersari pada pelarut etanol daripada senyawa yang larut air karena ekstrak daun nangka memiliki kandungan senyawa yang bersifat kurang polar sehingga senyawa lebih terlarut pada pelarut etanol dibandingkan air.
Penetapan kadar air dilakukan untuk mengetahui besarnya kadungan air dalam ekstrak, jumlah air yang sangat tinggi dapat menjadi media pertumbuhan bagi mikroorganisme yang dapat merusak mutu dan kandungan senyawa dalam ekstrak [3]. Hasil pengujian kadar air ekstrak daun sirsak sebesar 6,60\%, menunjukkan bahwa hasil ini memenuhi persyaratan yang ditetapkan MMI.

\section{Evaluasi sifat fisik granul effervescent}

Evaluasi sifat fisik yang dilakukan meliputi laju alir, sudut diam, densitas, kompresibilitas, kelembaban, $\mathrm{pH}$ larutan dan waktu larut. Data dibawah ini merupakan data yang diperoleh dari evaluasi granul effervescent ekstrak daun nangka.

Evaluasi sifat alir granul perlu dilakukan untuk mengetahui apakah granul mempunyai sifat alir yang baik atau tidak. Tabel 3 menunjukkan bahwa seluruh formulasi memiliki kecepatan alir granul yang baik yaitu lebih dari 10 $\mathrm{g} / \mathrm{s}$. kecepatan alir granul dipengaruhi oleh bentuk dan ukuran granul [9]. 
Semakin besar ukuran granul maka sifat alir semakin baik. Selain itu, sifat alir yang baik juga dipengaruhi oleh kohesivitas [3]. Dari evaluasi kecepatan alir ini menunjukkan bahwa adanya perbedaan konsentrasi asam dapat mempengaruhi kecepatan alir granul. Semakin bertambahnya konsentrasi asam tartrat maka kecepatan alirnya akan semakin baik. Dari ketiga formula menunjukkan bahwa F1 memiliki laju alir yang lebih baik dibandingkan F2 dan F3. Berdasarkan literatur asam tartrat mempunyai densitas yang lebih besar dibandingkan dengan asam sitrat sehingga granul yang mengandung lebih banyak asam tartrat akan mempunyai densitas yang lebih besar. Densitas yang besar menunjukkan bobot molekul yang besar sehingga akan lebih mudah mengalir karena gaya gravitasi yang lebih besar [7].

Sudut diam merupakan sudut maksimum yang dibentuk oleh permukaan serbuk granul dengan bidang horizontal. Sudut diam berkaitan dengan sifat alir granul yang akan dihasilkan. Bila sudut diam lebih kecil atau sama dengan $30^{\circ}$ menunjukkan bahwa bahan dapat mengalir bebas, bila sudutnya lebih besar atau sama dengan $40^{\circ}$ biasanya sifat alirnya kurang baik. Data hasil sudut diam yang di dapat menunjukkan bahwa F1, F2, dan F3 berdasarkan tabel hubungan sudut diam dan sifat alir granul memenuhi syarat, menghasilkan sudut diam kurang dari $25^{\circ}$ sehingga sifat alir yang dihasilkan sangat baik. Perbedaan besar kecilnya sudut diam pada ke tiga formula dipengaruhi oleh konsentrasi asam sitrat dan asam tartrat dimana pada F1 memiliki nilai sudut diam yang lebih kecil dibandingkan F2 dan F3 hal ini dikarenakan asam tartrat memiliki bobot molekul yang besar dan berpengaruh terhadap ukuran partikel. Dimana semakin besar ukuran partikel maka kohesivitas partikel semakin kecil dan akan meningkatkan kecepatan alir sehingga sudut diam yang terbentuk lebih kecil [9].

Nilai kompresibilitas dipengaruhi oleh bentuk, kerapatan, serta ukuran granul [3]. Dari hasil penelitian didapat nilai kompresibilitas F1, F2, dan F3 telah memenuhi persyaratan kompresibilitas yaitu pada range 5-15\% termasuk kategori istimewa. Bentuk dan ukuran granul yang seragam akan mempermudah dalam proses pengempaan menjadi tablet. Semakin besar ukuran partikel akan mengurangi fines yang terbentuk, hal ini menyebabkan kecilnya rongga yang terbentuk saat pencetakkan tablet [9].

Kadar air yang diperbolehkan yaitu 2-4\% [9]. Data hasil penelitian menunjukkan bahwa F1, F2, dan F3 tidak memenuhi persyaratan granul yang diperbolehkan. Hal ini dapat dipengaruhi adanya kelembaban ruangan dan nilai kadar air pada F1 lebih besar dibandingkan F2 dan F3 hal ini dapat disebabkan karena sifat sumber asam yang digunakan. Dimana asam tartrat memiliki sifat yang lebih higroskopis dibandingkan asam sitrat. Sehingga hal ini menyebabkan nilai kadar air pada F1 lebih tinggi dibandingkan F2 dan F3 [4].

Granul effervescent ekstrak daun nangka yang dihasilkan bersifat sedikit asam dengan rentang $\mathrm{Ph} 5,18-5,45$. Sifat asam ini diperoleh dari sifat asam sitrat yang lebih asam dibandingkan dengan asam tartrat sehingga pada F3 memilki nilai $\mathrm{pH}$ yang lebih asam dibandingkan F2 dan F3. Selain itu sifat dari ekstrak daun nangka juga mempengaruhi $\mathrm{pH}$ pada sediaan dimana dalam ekstrak daun nangka terkandung senyawa flavonoid, yaitu senyawa turunan fenol yang bersifat asam. Rasa asam dikarenakan banyaknya ion hidrogen dari flavonoid yang terionisasi [13].

Hasil yang didapat menunjukkan bahwa variasi konsentrasi asam sitrat dan asam tartrat mempengaruhi waktu larut sediaan granul effervescent dimana pada 
F1 memiliki waktu larut yang lebih cepat dibandingkan dengan F2 dan F3. Hal ini dapat disebabkan oleh sifat dari sumber asam dimana asam tartrat memiliki sifat yang lebih higroskopis dibandingkan dengan asam sitrat sehingga lebih mudah menyerap air dan bereaksi lebih cepat dibandingkan dengan F2 dan F3 yang jumlah asam tartratnya lebih sedikit. Persyaratan waktu larut yang baik yaitu kurang dari 5 menit [12].

\section{KESIMPULAN}

Berdasarkan penelitian yang telah dilakukan maka dapat disimpulkan bahwa Ekstrak daun nangka memiliki sifat fisika berwujud kental, berwarna hijau kehitaman, dan beraroma kuat dengan kadar air, senyawa larut air dan senyawa larut etanol berturut-turut adalah sebesar 6,60\%; 29,31\%; dan 36,76\% serta hasil perbedaan variasi konsentrasi asam sitrat dan asam tartrat berpengaruh terhadap sifat fisik granul effervescent ekstrak daun nangka menghasilkan F1 yang paling memenuhi persyaratan sifat fisik granul dibandingkan F2 dan F3 yaitu pada nilai laju alir, sudut diam, $\mathrm{pH}$ larutan dan waktu dispersi.

\section{DAFTAR PUSTAKA}

[1] Adnyani, Ni Made Rica Dwi dkk. Potensi Ekstrak Daun Nangka (Artocarpus heterophyllus Lam.) Sebagai Antioksidan Alami. Jurnal Kimia 10 (2), JULI 2016: 162-167.

[2] Anam, C., Kawiji., \& Setiawan, R., 2013, Kajian Karakteristik Fisik dan Sensori Serta Aktivitas Antioksidan dari Granul Effervescent Buah Beet (Beta Vulgaris) Dengan Perbedaan Metode Granulasi Dan Kombinasi Sumber Asam, Jurnal Tekno Sains Pangan, 2(2), 2302-0733.

[3] Apsari, Puput Andi dkk., 2017. Formulasi Tablet Effervescent Ekstrak Melinjo (Gnetum gnemon L.) Menggunakan PEG 6000 Sebagai Lubrikan dan Asam Sitrat-Asam Tartrat Sebagai Sumber Asam.
Jurnal ilmu-ilmu MIPA. ISSN: 14111047.

[4] Davies, Philip R. And Michael Bowker. 2009. Scanning Tunneling Microscopy In Surface Science, Nanoscience and Catalysis. United Kingdom. Cardiff University.

[5] Departemen Kesehatan RI. 1980. Materia Medika Indonesia Jilid IV. Direktorat Jenderal Pengawasan Obat dan Makanan. Jakarta.

[6] Departemen Kesehatan Republik Indonesia. 2000. Parameter Standar Umum Ekstrak Tumbuhan Obat Edisi I. Direktorat Jenderal Pengawasan Obat dan Makanan, Direktorat Pengawasan Obat Tradisional. Jakarta.

[7] Egeten, Krysta Riani dkk., 2016. Formulasi dan Pengujian Sediaan Granul Effervescent Sari Buah Nanas (Ananas comosus L.(Merr.)). Jurnal Ilmiah Farmasi -UNSRAT Vol.5 No.3. ISSN: 2302-2493.

[8] Marianne, Yuandani, dan Rosnani, 2011. Antidiabetic Activity From Ethanol Extract Of Kluwih's Leaf (Artocarpus heterophyllus L), Jurnal Natural, 11 (2): 64-68

[9] Mindawarnis dan Desti Hasanah. 2017. Formulasi Sediaan Tablet Ekstrak Daun Nangka (Artocarpus heterophyllus L.) Dengan Variasi Polivinil Pirolidon (PVP) Sebagai Pengikat Dan Evaluasi Sifat Fisiknya. Jurnal Kesehatan VoL. 12 No. 1.

[10] Omar, Haidy S, et al. Antioxidant Activity of Artocarpus heterophyllus Lam. (Jack Fruit) Leaf Extract: Remarkable Attenuations of Hyperglycemia and Hyperlipidemia in Streptozotocin-Diabetic Rats. The Scientific World JOURNAL. (2011) 11. 788-800 ISSN 1537-744X; DOI 10.110/tsw. 2011. 71.

[11]Prakash, Om., K, Rajesh., M, Anurag., and G, Rajiv. 2009. Artocarpus heterophyllus (Jackfruit): 
An overview, india : Review Article, 23 (6): 353-358.

[12]S, Yameela dan Suprapto. 2016. Pengaruh Penggunaan Polivinil Pirolidon (PVP) Sebagai Bahan Pengikat Terhadap Sifat Fisik dalam Formulasi Sediaan Granul Effervesecnt Ekstrak Buah Asam Gelugur (Garcinia atroviridisGGriff. Et Anders). ISSN: 2557-533X.
[13]Wijayanti, Muthmaina dkk., 2014. Formulasi Granul Effervescent Sari Kering Lidah Buaya Sebagai Makanan Tambahan. Vol.1 No.1.IJPST. 